\title{
Diabetes-Induced Prefrontal Nissl Substance Deficit and the Effects of Neem-Bitter Leaf Extract Treatment
}

\author{
Diabetes Inducida por Déficit Prefrontal de Sustancia de Nissl y el Efecto del Tratamiento con \\ Extracto de Hoja de Neem Amargo
}

"Oluwole B. Akinola; "Olaiya G. Omotoso; ** Olufunke O. Dosumu; "Oluwafunmike S. Akinola \& "Favour Olotufore

AKINOLA, O. B.; OMOTOSO, O. G.; DOSUMU, O. O.; AKINOLA, O. S. \& OLOTUFORE, F. Diabetes-Induced prefrontal Nissl substance deficit and the effects of Neem-Bitter leaf extract treatment. Int. J. Morphol., 29(3):850-856, 2011.

SUMMARY: Cognitive dysfunction is reportedly associated with poorly-managed diabetes mellitus. In this study, we report the effect of oral treatment with combined leaf extract (CLE) of neem and bitter leaf on the prefrontal cortex of diabetic Wistar rats. Adult male Wistar rats were randomized to one of the following groups: control, diabetic (STZ-induced), STZ + CLE, STZ + metformin and CLE only. At euthanasia, paraffin sections of the prefrontal cortex were stained with cresyl fast violet; while malondialdehyde (MDA) and glutathione peroxidase (GPx) were assayed in prefrontal homogenates. Oral CLE produced normoglycemia in the treated hyperglycaemic rats. Besides, Nissl-stained prefrontal sections showed no morphologic deficits in all the groups except the untreated diabetic rats. In the latter, there was weak Nissl staining, while prefrontal MDA was significantly high at euthanasia, compared with the control and CLE-treated rats $(\mathrm{P}<0.05)$. This study showed that untreated diabetes mellitus is associated with prefrontal Nissl body deficit and oxidative stress in Wistar rats. The absence of these deficits in CLE-treated rats suggests a neuroprotective effect of the extract in streptozotocin-induced diabetic rats. This may improve the cognitive function of the prefrontal cortex in diabetes mellitus.

KEY WORDS: Pyramidal cells; Hyperglycaemia; Oxidative stress; Cognition.

\section{INTRODUCTION}

Diabetic complications involve numerous organs and systems. Complications involving vital organs such as the heart, kidney, liver, eye and blood vessels are well known. In addition, neural complications, with varying degrees of neurobehavioral manifestations, are associated with chronic poorly treated diabetes mellitus.

In type 1 diabetes mellitus, Miles \& Root (1922) reported cognition dysfunction (characterized by memory and attention impairment) in the studied subjects. Subsequent studies in type 1 diabetics reported deficits such as psychomotor inefficiency (Weinger et al., 2008), impairment of general intelligence (Northam et al., 2001) and deficits in motor speed (Wessels et al., 2007). In type 2 diabetes, cognitive impairments include deficits in executive function (Raeven $e t$ al., 1990), working memory (Munshi et al., 2006), and verbal fluency (Raeven et al.). Such patients also show increased incidence of Alzheimer's disease and vascular dementia (Ott et al., 1996), as well as increased incidence of depression, which negatively effects cognition (Munshi et al.).
Several factors are involved in the pathophysiology of cognitive decline in diabetes. Some of these factors are however conjectural. Factors such as hyperglycaemia (Toth et al., 2006), hypoglycaemia and vascular disease (McCall, 1992), amyloidosis and insulin resistance (Janson et al., 2004) were implicated. In addition, oxidative stress (characterised by increased superoxide anion formation in the presence of chronic hyperglycaemia) is involved in the pathogenesis of diabetic cognitive impairment (Brownlee, 2005). Recent study also reported inverse association between body mass index and prefrontal metabolic activity (Volkow et al., 2008); and the report of Toth et al. associated cognitive dysfunction and dementia with chronic hyperglycaemia.

Owing to the reported involvement of hyperglycaemia and oxidative stress in the pathogenesis of diabetic cognitive dysfunction (Toth et al.), and the growing interest in complementary and alternative medicine (CAM) for the management of diabetes mellitus, we

\footnotetext{
* Department of Anatomy, Faculty of Basic Medical Sciences, University of Ilorin, P.M.B. 1515, Ilorin 240003, Nigeria.

** Department t of Anatomy College of Medicine University of Lagos, Nigeria.
} 
studied the effects of neem-bitter leaf extract on hyperglycaemia, prefrontal cortex morphology and prefrontal oxidative stress in streptozotocin-induced diabetic Wistar rats.

\section{MATERIAL AND METHOD}

Plant materials. Mature fresh leaves of neem were collected in the premises of the University of Ilorin (Mini Campus), Nigeria. Mature fresh leaves of bitter leaf were obtained from a botanical garden in Ilorin, Nigeria. Both plants were collected in October 2009, and were authenticated at the Herbarium of the University of Ilorin, where they were compared to the herbarium specimens (voucher numbers: neem (542); bitter leaf (10)).

The leaves were separately shade-dried and pulverized. Ethanolic extraction was done for each dry leaf material using $70 \%$ ethanol (in a percolator) at room temperature $\left(23^{\circ} \mathrm{C}\right)$. The extracts were evaporated to dryness in a water bath at $45^{\circ} \mathrm{C}$. A compound herbal extract was thereafter prepared at a ratio of 5:4 (neem: bitter leaf).

Animals. Male Wistar rats (2 months old; and bred in the Animal Holdings of Anatomy Department, University of Ilorin) were randomized to one of the following treatment groups: control, diabetic group, streptozotocin + combined leaf extract (STZ + CLE), STZ + metformin, and CLE only. Each group consisted of eight animals. Fasted rats were induced to hyperglycaemia with intraperitoneal STZ $(70 \mathrm{mg} /$ $\mathrm{kg}$ body weight), in sodium citrate buffer (0.1 M, pH 4.5). Animals with fasting blood glucose $250 \mathrm{mg} / \mathrm{dl}$ or more $(96$ hours post-STZ induction) were included in the study. CLE was administered orally at $500 \mathrm{mg} / \mathrm{kg}$ body weight/day (500 $\mathrm{mg} / \mathrm{kg} \mathrm{bw} / \mathrm{d}$ ), while oral metformin was administered at 150 $\mathrm{mg} / \mathrm{kg}$ bw/d (Matsui et al. 2010). All rats were treated for eight weeks. Animals were exposed to 12-hour light:12hour dark photo cycle; and were maintained on pelletized rat feed (Bendel Feed, Nigeria). Food and water were served ad libitum.

Estimation of blood glucose and termination of treatment. Starting at day 0 , blood glucose was estimated at alternate days by the glucose oxidase method using the One-touch glucometer (Lifescan, CA, USA). After the last dose of CLE and metformin, all animals were fasted for 12 hours and then placed under anaesthesia (diethyl ether, Sigma, USA). Laparatomy was performed and brains were fixed in chilled $4 \%$ paraformaldehyde. Moreover, $10 \%$ homogenates of the prefrontal lobes were prepared in phosphate buffer (0.1 M, pH 7.4).
Estimation of prefrontal malondialdehyde (MDA) and glutathione peroxidase (GPx) and histological staining. Prefrontal MDA was estimated by the thiobarbituric acid test (Ohkawa et al., 1979). GPx activity was determined by the method of Paglia \& Valentine (1967) and total prefrontal protein by the Biuret method (Weichselbaum, 1946) using kits from Randox Laboratories (Antrim, UK). Prefrontal lobes of rats brains were fixed in $4 \%$ paraformaldehyde and processed for paraffin embedding. Paraffin sections $(5 \mu)$ were stained with cresyl fast violet (Bancroft \& Stevens, 1982) to study the morphology of the prefrontal neurons.

Statistical analysis. Data collected on blood glucose, body weight, MDA, and GPx were analysed by one-way analysis of variance (ANOVA). Statistical significance was accepted at $95 \%$ confidence interval.

\section{RESULTS}

Blood glucose and body weight. Figure 1 shows the mean blood glucose concentrations of each group of rats. Blood glucose in the untreated diabetic group remained significantly higher than the control group throughout the study period $(\mathrm{P}<0.05)$. Meanwhile, metformin and CLE treatment produced normoglycaemia in the induced diabetic rats during the treatment period, such that blood glucose in these treated animals were not significantly different from control $(\mathrm{P}>0.05)$ at the end of the treatment period (Fig. 1).

The difference in body weight of each of the rats was estimated and expressed as percentage change in body weight (Fig. 2). This was calculated as follows:

Change in body weight $(\%)=($ final body weight initial body weight) x 100 / (initial body weight).

Prefrontal malondialdehyde and glutathione peroxidase levels. Figure 3A shows prefrontal levels of malondialdehyde (MDA) in the treatment and control rats. Significant increases in MDA occurred in the diabetic and metformintreated rats compared with the control $(\mathrm{P}<0.05)$. Similarly, significant increases in prefrontal GPx occurred in the metformin group, compared with the control $(\mathrm{P}<0.05)$ (Fig. 3B).

Prefrontal cortex histology. Figure 4 shows sections through the prefrontal cortex of the rats. Nissl staining outcomes were similar in all the groups except the untreated diabetic group. In the latter, pyramidal cells showed weak affinity for Nissl stain, and the prefrontal cortex showed generalized poor Nissl-staining characteristic. 


\section{DISCUSSION}

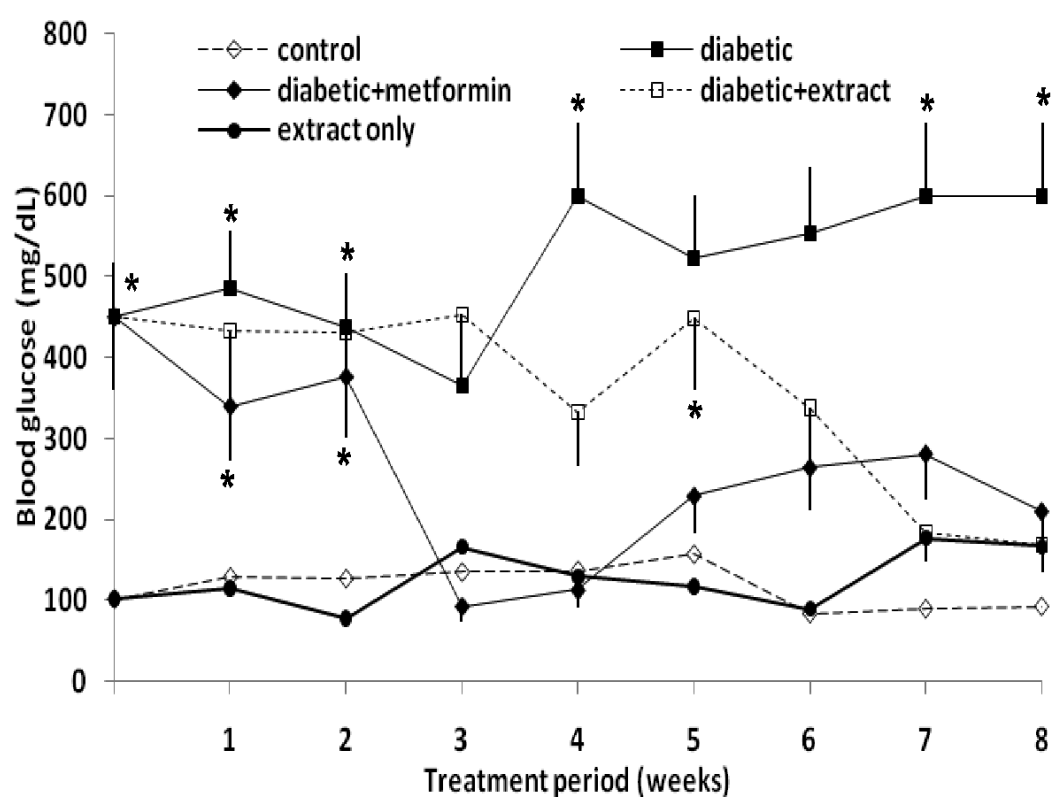

Fig. 1. Blood glucose concentrations of control and treatment groups over a period of 8 weeks. Data are means \pm SEM. * Significantly different from control $(\mathrm{P}<0.05)$.

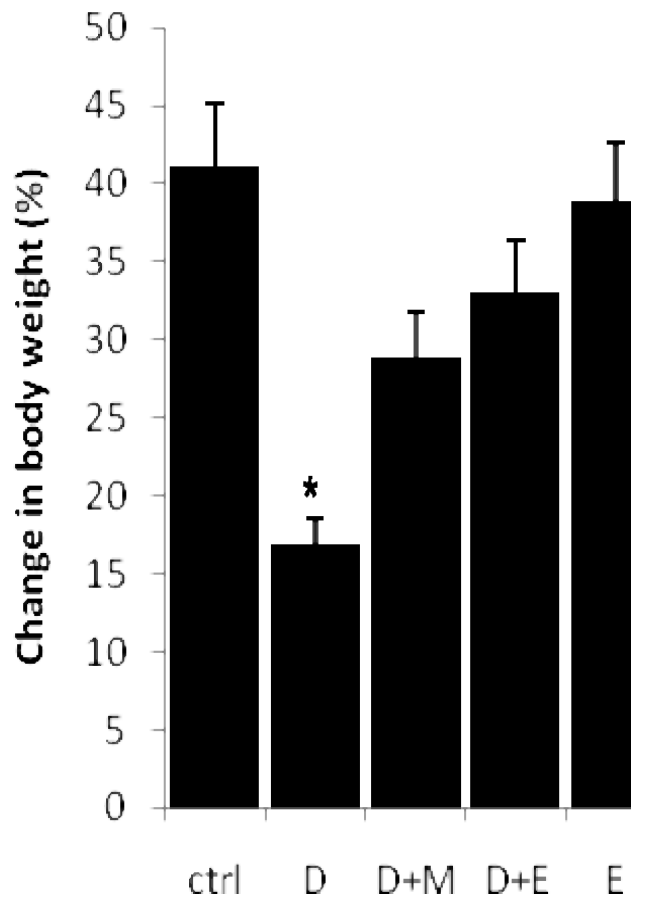

Fig. 2. Changes in body weights of the animals (expressed in percentage). Data are mean \pm SEM. *Significantly different from control $\quad(\mathrm{P}<0.05) . \quad \mathrm{Ctrl}=\mathrm{control} ; \quad \mathrm{D}=$ diabetic; $\mathrm{D}+\mathrm{M}=$ diabetic+metformin; $\mathrm{D}+\mathrm{E}=$ diabetic+extract; $\mathrm{E}=$ extract only.
In the present study, daily oral administration of CLE to diabetic Wistar rats resulted in significant reductions in blood glucose concentrations in the course of the treatment (Fig. 1). This shows that CLE has ameliorative effects on hyperglycaemia. This finding corroborates the report of Ebong et al. (2008) who observed amelioration of hyperglycaemia in alloxan-induced diabetic Wistar rats on a daily oral regimen of CLE at $400 \mathrm{mg} / \mathrm{kg}$ body weight/day (400 mg/kg bw/d) for 24 days. Moreover, earlier study of the ethanolic leaf extract of neem in our laboratory showed that this extract improved hyperglycaemia in streptozotocin-induced diabetic rats. In these rats, hyperglycaemia was reversed within the first week of oral treatment with neem leaf extract (Akinola et al., 2010). Similarly, additional work in our laboratory showed that, when administered to diabetic Wistar rats at an oral dose of $400 \mathrm{mg} / \mathrm{kg}$ bw/d, ethanolic leaf extract of bitter leaf ameliorated hyperglycaemia within the 21day treatment period (Akinola et al., 2009). This supports the findings of Osinubi (2006) who reported amelioration of hyperglycaemia in an acute study of alloxan-induced Sprague-Dawley rats treated orally with aqueous leaf extract of bitter leaf at $500 \mathrm{mg} / \mathrm{kg}$ bw. These findings suggest that when administered as monotherapies, leaf extracts of neem and bitter leaf possess hypoglycaemic property. The combined leaf extract of these plants also showed similar effect in the present study, without any relative advantage over neem and bitter leaf monotherapies. Moreover, improvement of hyperglycaemia in the CLE-treated and metformin-treated rats was associated with improved body weights in these groups compared to the untreated diabetic group (Fig. 2).

In Figure 4, Nissl-stained sections of the prefrontal cortex showed poor staining outcome in the untreated STZ-induced diabetic rats compared with the control and CLE-treated rats. The weak staining characteristic of the prefrontal pyramidal cells in these diabetic rats suggests loss or reduction of Nissl bodies of these cells; and 

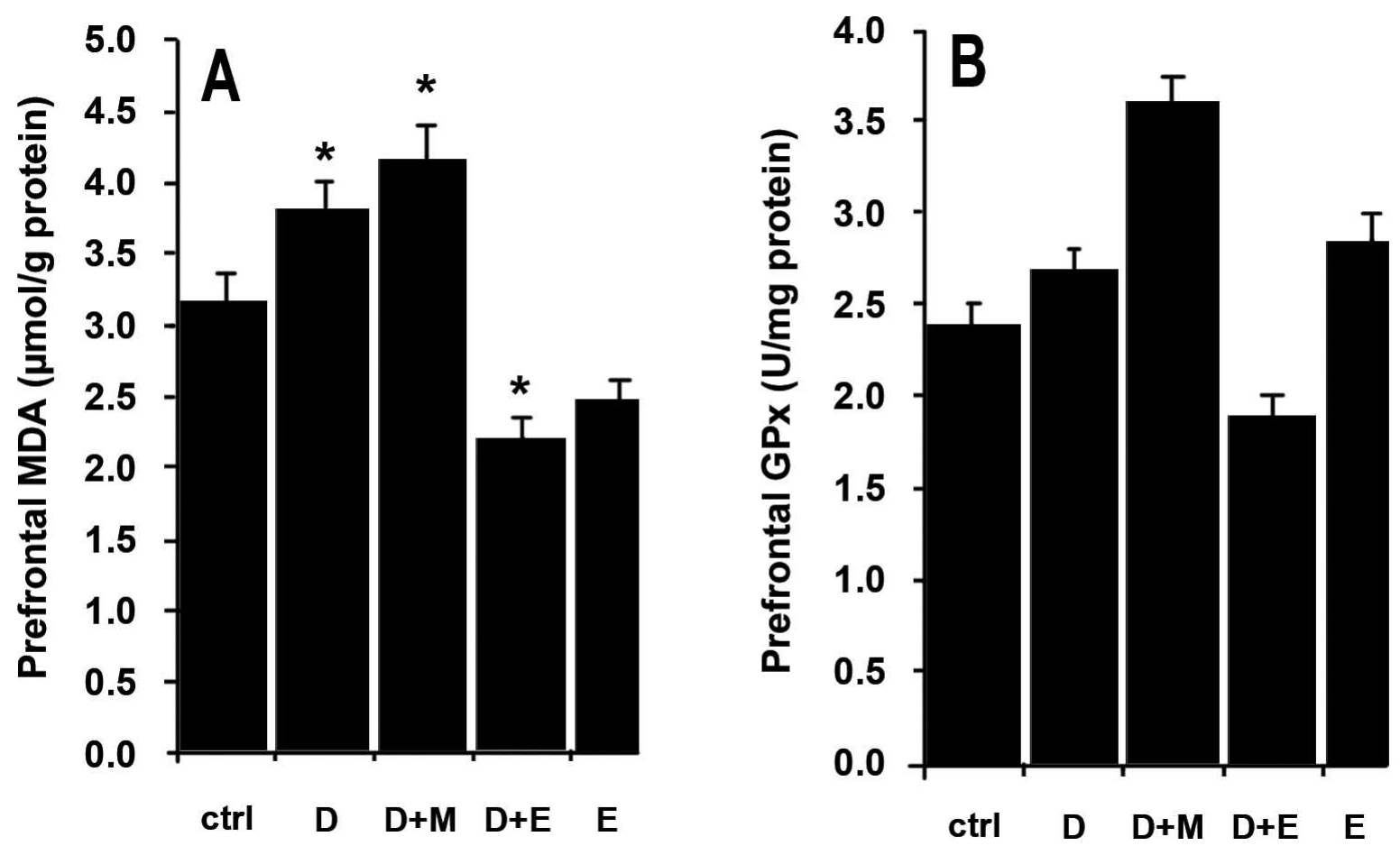

Fig. 3 (A-B). A, prefrontal MDA; B, prefrontal GPx of the control and treatment groups. Data are mean \pm SEM. *Significantly different from control $(\mathrm{P}<0.05)$. $\mathrm{Ctrl}=$ control; $\mathrm{D}=$ diabetic; $\mathrm{D}+\mathrm{M}=$ diabetic+metformin; $\mathrm{D}+\mathrm{E}=$ diabetic+extract; $\mathrm{E}=\mathrm{extract}$ only.
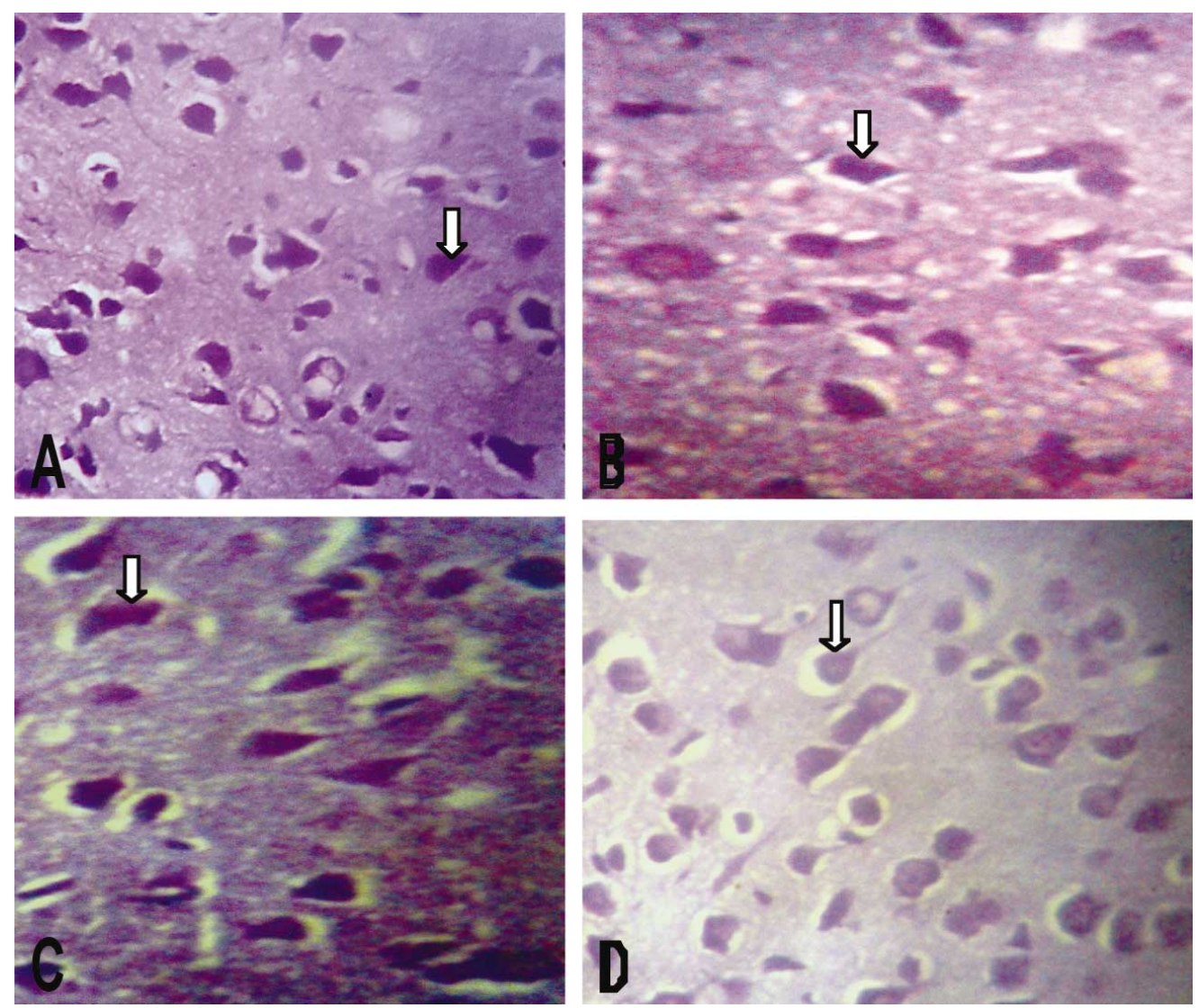

Fig. 4. Sections through lamina $\mathrm{V}$ of the prefrontal cortex of the treatment and control rats. Pyramidal cells are indicated by the arrows. In the untreated diabetic rats, the Nissl granules of the prefrontal cortex were poorly stained as indicated by the relatively pale appearance of the cortex. A, control; $\mathrm{B}$, diabetic group; C, diabetic+extract; D, diabetic+metformin. Nissl stain, x600. 
this implies decreased synthetic activity of the pyramidal neurons, with possible impairment of cognitive function in these animals. In this study however, behavioural and cognitive tests were not performed on the animals. In the recent study of Joghataie et al. (2007), which evaluated time-dependent anatomic changes in the medial prefrontal cortex of male STZ-induced diabetic rats, a significant reduction in the mean density of pyramidal neuron dendritic spines of medial prefrontal cortex, two months after the induction of diabetes, was reported. The present histologic findings from our work, and previous findings such as those of Joghataie et al. showed that diabetes mellitus is associated with morphologic changes in the prefrontal grey matter. A similar work reported by Nitta et al. (2002) showed significant decreases in the number of basal dendrites and abnormal spine structure in the neurons of the cerebral cortex of STZ-induced diabetic rats, at 4 weeks post-induction. In addition, both protein and mRNA levels of brain-derived neurotrophic factor (BDNF) were reportedly reduced in the diabetic rats. The latter finding is supported by the morphologic findings in our study. Weak Nissl staining outcome in the prefrontal cortex of diabetic rats suggests reduction of the ribonucleic acid of the rough endoplasmic reticulum of pyramidal cells (with implications for impaired functional activity of these cells and of the prefrontal cortex). Additional anatomic evidence that diabetes has adverse effects on prefrontal morphology came from the study of Kumar et al. (2008). Using magnetic resonance imaging (MRI), these authors demonstrated specific neuroanatomic deficits in the prefrontal grey matter of type 2 diabetics. Such deficits included smaller total brain grey matter volumes, reduced grey matter volumes in the anterior cingulate and orbitofrontal regions compared with control. These changes in brain grey matter volumes were suggested to have implications for the behavioural sequelae of diabetes mellitus.

Increased brain oxidative damage is reportedly associated with cognitive decline and Alzheimer's dementia (Pratico et al., 2002). The deleterious effects of chronic fasting hyperglycaemia on cognition in the diabetics may be mediated via increased generation of free radicals. Supraphysiologic levels of blood glucose would overdrive the electron transport system, resulting in excessive production of superoxide anion (Nishikawa et al., 2000). Moreover, autoxidation of the excess glucose, in the presence of transition metals, as well as nonenzymatic glycation of proteins, would generate reactive oxygen species in the diabetics (Wolff et al., 1989). Chronic hyperglycaemia can also lower the activity of antioxidant enzymes, perhaps by means of glycation (Blakytny \& Harding, 1992). In the present work, significantly increased prefrontal levels of malondialdehyde (MDA) occurred in the untreated diabetic rats at 8 weeks post-diabetes induction (Fig. 3A). Metformin-treated diabetic rats showed similar significant increases in prefrontal MDA. However, in these animals, cognitive tests were not performed, and therefore, it is unclear whether the observed elevated prefrontal MDA was associated with cognitive (neurobehavioural) deficits in these animals. Nonetheless, recent study of Kumar et al. (2009) showed that increased brain oxidative stress in colchicine-treated Wistar rats was associated with cognitive impairment, as indicated by the results of Morris water maze and plus-maze performance tests.

In our study, CLE treatment produced significantly low prefrontal MDA (Fig. 3A), without any significant changes in prefrontal GPx levels (Fig. 3B). Moreover, Nissl-stained sections of the prefrontal cortex showed no striking histologic differences between the CLE-treated rats and the controls. These findings suggest that CLEtreatment had beneficial effects on the prefrontal cortex of STZ-induced diabetic rats. Metformin treatment did not confer similar benefit against prefrontal oxidative stress, as prefrontal MDA levels were significantly higher than controls (Fig. 3A). Regarding the effects of CLE, its exact protective mechanism on the prefrontal cortex was not elucidated in the present study, but our findings suggest that it had antioxidant-like activity. In the work of Kumar et al. (2009), Centella Asiatica treatment protected against colchicine-induced cognitive impairment and oxidative stress in Wistar rats, and it was concluded that the administered extract produced its protective effect on cognition through an antioxidant-like mechanism. Similarly, Rogers et al. (2003) studied the effect of ad libitum apple juice supplementation on oxidative stress and cognitive deficits in normal and transgenic mice lacking apolipoprotein $\mathrm{E}$ and deprived of folic acid and vitamin E. They reported a protective effect of the fruit supplement against oxidative stress and cognitive impairment in the studied mice. In addition, Ohwada et al. (2008) studied the association of oxidative stress with cognitive deficit in rats. Treatment of rats with pyrroloquinoline quinone (PQQ) improved learning outcomes in the treated rats compared to controls. Thus, the previous and present findings suggest that dietary and botanical interventions could improve prefrontal morphology and cognition in diabetic and/or memoryimpaired animals. Specifically, the present study showed that the combined leaf extract of neem and bitter leaf protected against diabetes-induced prefrontal Nissl substance deficit and oxidative stress; and additional studies to isolate the phytochemicals responsible for these effects are ongoing in our laboratory. 
AKINOLA, O. B.; OMOTOSO, O. G.; DOSUMU, O. O.; AKINOLA, O. S. \& OLOTUFORE, F. Diabetes inducida por déficit prefrontal de sustancia de Nissl y el efecto del tratamiento con extracto de hoja de Neem amargo. Int. J. Morphol., 29(3):850-856, 2011.

RESUMEN: La disfunción cognitiva es presuntamente asociada con un mal manejo de la diabetes mellitus. En este estudio, se presenta el efecto del tratamiento oral combinado con extracto de hoja (CLE) de hoja de neem amarga sobre la corteza prefrontal de ratas Wistar con diabetes. Las ratas Wistar adultas fueron asignadas al azar a uno de los siguientes grupos: control, diabetes (STZ inducida), STZ + CLE, STZ + metformina y CLE. Después de la eutanasia, los cortes de parafina de la corteza prefrontal se tiñeron con violeta de cresil rápido, mientras que el malondialdehído (MDA) y la glutatión peroxidasa (GPx) fueron analizadas en homogenizados prefrontales. El CLE produce normoglucemia en las ratas hiperglucémicas tratadas. Además, las secciones prefrontales teñidas para Nissl no muestran ningún déficit morfológico en todos los grupos excepto en las ratas diabéticas sin tratamiento. En este último caso, hubo una tinción de Nissl débil, mientras que la MDA prefrontal fue significativamente más alta en comparación con los grupos de ratas control y las tratadas con CLE ( $\mathrm{p}<0,05)$. Este estudio mostró que la diabetes mellitus no tratada se asocia con déficit prefrontal de cuerpos de Nissl y estrés oxidativo en ratas Wistar. La ausencia de estos déficits en las ratas tratadas CLE, sugiere un efecto neuroprotector del extracto en ratas diabéticas inducidas por estreptozotocina. Esto puede mejorar la función cognitiva de la corteza prefrontal en la diabetes mellitus.

PALABRAS CLAVE: Células piramidales; Hiperglicemia; Estrés oxidativo; Cognición.

\section{REFERENCES}

Akinola, O. S.; Akinola, O. B. \& Caxton-Martins, E. A. Vernonia amygdalina upregulates hepatic enzymes and improves liver microanatomy in experimental diabetes mellitus. Pharmacologyonline, 2:1231-42, 2009.

Akinola, O. B.; Caxton-Martins, E. A. \& Dini, L. Chronic Treatment with Ethanolic Extract of the Leaves of Azadirachta indica Ameliorates Lesions of Pancreatic Islets in Streptozotocin Diabetes. Int. J. Morphol., 28(1):291-302, 2010.

Bancroft, J. \& Stevens, A. Theory and Practice of Histological Techniques. $2^{\text {nd }}$ Edn. New York, Churchill Livingston, 1982. pp.131-5.

Blakytny, R. \& Harding, J. J. Glycation (non-enzymatic glycosylation) inactivates glutathione reductase. Biochem. J., 288(1):303-7, 1992.

Brownlee, M. The pathobiology of diabetic complications: a unifying mechanism. Diabetes, 54(6):1615-25, 2005.

Ebong, P. E.; Atangwho, I. J.; Eyong, U. E.; \& Egbung, G. E. The antidiabetic efficacy of combined extracts from two continental plants: Azadirachta indica (A. Juss) (Neem) and Vernonia amygdalina (Del.) (African Bitter Leaf). Am. J. Biochem. Biotechnol., 4:239-44, 2008.

Janson, J.; Laedtke, T.; Parisi, J. E.; O'Brien, P.; Petersen, R. C. \& Butler, P. C. Increased risk of type 2 diabetes in Alzheimer disease. Diabetes, 53:474-81, 2004.

Joghataie, M. T.; Roghani, M.; Jalali, M. R.;
Baluchnejadmojarad, T. \& Sharayeli, M. Dendritic Spine Changes in Medial Prefrontal Cortex of Male Diabetic Rats Using Golgi-Impregnation Method. Arch. Iran. Med., 10(1):54-8, 2007.

Kumar, A.; Dogra, S. \& Prakash, A. Neuroprotective effects of Centella asiatica against intra-cerebroventricular colchicine-induced cognitive impairment and oxidative stress. Int. J. Alzheimers Dis., pii: 972178, 2009.

Kumar, A.; Haroon, E.; Darwin, C.; Pham, D.; Ajilore, O.; Rodriguez, G. \& Mintz, J. Gray matter prefrontal changes in type 2 diabetes detected using MRI. $J$. Magn. Reson. Imaging, 27(1):14-9, 2008.

Matsui, Y.; Hirasawa, Y.; Sugiura, T.; Toyoshi, T.; Kyuki, K. \& Ito, M.Metformin reduces body weight gain and improves glucose intolerance in high-fat diet-fed C57BL/6J mice. Biol. Pharm. Bull., 33(6):963-70, 2010.

McCall, A. L. The impact of diabetes on the CNS. Diabetes, 41(5):557-70, 1992.

Miles, W. R. \& Root, H. F. Psychologic tests applied to diabetic patients. Arch. Intern. Med., 30(6):767-77, 1922.

Munshi, M.; Grande, L.; Hayes, M.; Ayres, D.; Suhl, E.; Capelson, R.; Lin, S.; Milberg, W. \& Weinger, K. Cognitive dysfunction is associated with poor diabetes control in older adults. Diabetes Care, 29(8):17949, 2006. 
Nishikawa, T., Edelstein, D.; Du, X. L.; Yamagishi, S.; Matsumura, T.; Kaneda, Y.; Yorek, M. A.; Beebe, D.; Oates, P. J.; Hammes, H. P.; Giardino, I. \& Brownlee, M. Normalizing mitochondrial superoxide production blocks three pathways of hyperglycaemic damage. Nature, 404(6779):787-90, 2000.

Nitta, A.; Murai, R.; Suzuki, N.; Ito, H.; Nomoto, H.; Katoh, G.; Furukawa, Y. \& Furukawa, S. Diabetic neuropathies in brain are induced by deficiency of BDNF. Neurotoxicol. Teratol., 24(5):695-701, 2002.

Northam, E. A.; Anderson, P. J.; Jacobs, R.; Hughes, M.; Warne, G. L. \& Werther, G. A. Neuropsychological profiles of children with type 1 diabetes 6 years after disease onset. Diabetes Care, 24(9):1541-6, 2001.

Ohkawa, H.; Ohishi, N. \& Yagi, K. Assay for lipid peroxides in animal tissues by thiobarbituric acid reaction. Anal. Biochem., 95(2):351-8, 1979.

Ohwada, K.; Takeda, H.; Yamazaki, M.; Isogai, H.; Nakano, M.; Shimomura, M.; Fukui, K. \& Urano, S. Pyrroloquinoline quinone (PQQ) prevents cognitive deficit caused by oxidative stress in rats. J. Clin. Biochem. Nutr., 42:29-34, 2008.

Osinubi, A. A. Effect of Vernonia amygdalina and chlorpropamide on blood glucose. Med. J. Islamic World Acad. Sci., 16:115-9, 2006.

Ott, A.; Stolk, R. P.; Hofman, A.; van Harskamp, F.; Grobbee, D. E. \& Breteler, M. M. Association of diabetes mellitus and dementia: the Rotterdam Study. Diabetologia, 39(11):1392-7, 1996.

Paglia, D. E. \& Valentine, W. N. Studies on the quantitative and qualitative characterization of erythrocyte glutathione peroxidase. J. Lab. Clin. Med., 70(1):15869, 1967.

Pratico, D.; Clark, C. M.; Liun, F.; Lee, V. Y. \& Trojanowski, J. Q. Increase of brain oxidative stress in mild cognitive impairment - a possible predictor of Alzheimer disease Arch. Neurol., 59(6):972-6, 2002.

Raeven, G. M.; Thompson, L. W.; Nahum, D. \& Haskins, E. Relationship between hyperglycemia and cognitive function in older NIDDM patients. Diabetes Care, 13(1):16-21, 1990.

Rogers, E. J.; Milhalik, S.; Ortiz, D. \& Shea, T. B. Apple juice prevents oxidative stress and impaired cognitive performance caused by genetic and dietary deficiencies in mice. J. Nutr. Health Aging, 8(2):92-7, 2003.

Toth, C.; Schmidt, A. M.; Tuor, U. I.; Francis, G.; Foniok, T.; Brussee, V.; Kaur, J.; Yan, S. F.; Martinez, J. A.; Barber, P. A.; Buchan, A. \& Zochodne, D. W. Diabetes, leukoencephalopathy and rage. Neurobiol. Dis., 23(2):445-61, 2006.

Volkow, N. D.; Wang, G. J.; Telang, F.; Fowler, J. S.; Goldstein, R. Z.; Alia-Klein, N.; Logan, J.; Wong, C.; Thanos, P. K.; Ma, Y. \& Pradhan, K. Inverse Association Between BMI and Prefrontal Metabolic Activity in Healthy Adults. Obesity, 17(1):60-5, 2008.

Weichselbaum, W. E. An accurate and rapid method for the determination of protein in small amounts of blood serum and plasma. Am. J. Clin. Path., 10:40-9, 1946.

Weinger, K.; Jacobson, A. M.; Musen, G.; Lyoo, I. K.; Ryan, C. M.; Jimerson, D. C. \& Renshaw, P. F. The effects of type 1 diabetes on cerebral white matter. Diabetologia, 51(3):417-25, 2008.

Wessels, A. M.; Rombouts, S. A.; Remijnse, P. L.; Boom, Y.; Scheltens, P.; Barkhof, F.; Heine, R. J. \& Snoek, F. J. Cognitive performance in type 1 diabetes patients is associated with cerebral white matter volume. Diabetologia, 20(8):1763-9, 2007.

Wolff, S. P., Bascal, Z. A. \& Hunt, J. V. Autoxidative glycosylation: free radicals and glycation theory. Prog. Clin. Biol. Res., 304:259-75, 1989.

Correspondence to:

Dr. Oluwole B. Akinola

Department of Anatomy

Faculty of Basic Medical Sciences

University of Ilorin, P.M.B. 1515

llorin 240003

NIGERIA

Tel.: +234-7032268248

Email: woleakinola@yahoo.com

Received: 26-12-2010

Accepted: 13-05-2011 